\title{
Consensus
}

Volume 25

Issue 1 Contextual Perspectives in Pastoral Care and

Article 13

Counselling

5-1-1999

\section{Priests, prophets, diviners, sages: a socio-historical study of religious specialists in ancient Israel}

Roger W. Uitti

Follow this and additional works at: http://scholars.wlu.ca/consensus

\section{Recommended Citation}

Uitti, Roger W. (1999) "Priests, prophets, diviners, sages: a socio-historical study of religious specialists in ancient Israel," Consensus: Vol. 25 : Iss. 1 , Article 13.

Available at: http://scholars.wlu.ca/consensus/vol25/iss1/13

This Book Reviews is brought to you for free and open access by Scholars Commons @ Laurier. It has been accepted for inclusion in Consensus by an authorized editor of Scholars Commons @ Laurier. For more information, please contact scholarscommons@wlu.ca. 
power for newness is at work in such displacements. Brueggemann is, in either case, careful not to mold the text to fit any particular contemporary situation. Instead, he insists, "our situation needs to be submitted to the text for a fresh discernment. In every generation this text subverts all our old readings of reality and forces us to a new, dangerous, obedient reading."

Brueggemann divides the 52 chapters of Jeremiah into 15 sections, each of which is accorded a summarizing title (e.g., "The Baruch document" 36:1-45:5; "Oracles against the Nations" 46:1-51:64, "Judgment and Hope" 21:1-25:38, etc.). The format lends itself well to research on specific pericopes not always defined by the traditional versing. Moreover, much of what Brueggemann has to say is repeated in many of the sections. One need not read the entire volume in order to retrieve critical elements of Brueggemann's theology. Each of the sections is subdivided into manageable pericopes that usually move inductively from word studies, examination of grammatical nuances, images, and metaphors, to generalizing comments and conclusions, which tie in with the larger theological themes Brueggemann weaves throughout his commentary.

This edition lacks a subject index, and is not edited for post-1990 European political reality. Brueggemann refers often to the Soviet Union as an example of "Empire". In his illustration of the prophet calling Israel to submit to Babylon, he cites as an example the Cold War rhetoric: "Better red than dead." Moreover, Brueggemann does not cite any works published later than the early 1990s. Despite these drawbacks, Brueggemann's work is a refreshing contribution to biblical interpretation, one that frees the biblical text to speak for itself and embraces the ambiguity and incongruity contained within.

Martin E. Malina

St. Peter's Lutheran Church,

Brodhagen, Ontario

\section{Priests, Prophets, Diviners, Sages: A Socio-Historical Study of Religious Specialists in Ancient Israel}

Lester L. Grabbe

Valley Forge, PA: Trinity Press International, 1995

xviii + 261 pages, \$20.00 US Paperback

This book by Lester L. Grabbe, Head of the Department of Theology and Professor of Hebrew Bible and Early Judaism at the University of Hull in Great Britain, is an example of the kind of sociology of ancient lsrael being written 
today. For this author it is not a question of whether or not certain religious specialists existed but to what extent their character and work can be determined from the sources available to us. Grabbe's approach is to focus on the present final Old Testament text and not get involved in the vagaries of source-, form- or traditio-critical analysis. His method is thus synchronic rather than diachronic. For each of five religious specialists Grabbe sets forth first the textual data, then draws upon cross-cultural parallels, sometimes from the ancient Near East alone but other times from broader anthropological studies. The end goal is to formulate a Weberian "ideal type" for each of these offices. Not surprisingly the most space is devoted to the prophet (51 pages). The prophet turns out to be a mediator who claims to have received messages direct from God, by a variety of means. While contemporary interests might urge us to see the prophets as "social reformers", Grabbe contends, judging from the contents of both the writing and the written-about prophets, the designation "political and religious critics" would be more accurate. On the other hand the space (33 pages) given over to the diviner/healer/shaman is arresting, as Grabbe holds up the importance of divination, concluding that many forms of divination were available to the common Israelite, including some consultation with the dead and probable involvement with a cult of the dead. Next in turn and length but equally rewarding are Grabbe's treatments of the sage (29 pages), the priest (25 pages), and the king (21 pages). One thing the author makes clear throughout the monograph is that the lines of demarcation between these religious "specialists" are not to be drawn too sharply. The neat, watertight categories we seek to find exist best in the mind, not in real society, as real society is a messy, inconsistent affair.

As I read this book I found myself occasionally resisting what I thought was a statement of overconfidence or a plain manipulation of the data to discover something less familiar or traditional. For example, I am not so certain that one can or should homogenize institutional functions across the ancient Near East to arrive at something different, such as the strong cultic role Grabbe gives to normative Israelite kingship. Incidentally, as the author does present five different religious specialists, I wonder why this very one, the king was left out of the book title. Furthermore, I am not disposed to accept the author's recurrent, confident identification of "the prophetess" of Isaiah 8:3, "with whom Isaiah had sex and produced several children", as definitely not the prophet Isaiah's wife, but most likely the same woman designated as "the young woman" in Isaiah 7:14 [74, 83, 101, 114, 202]. I liked the author's use of the Tetragrammaton to refer respectfully to the national God of Israel, but I would have preferred the use of "YHWH" rather than "Yhwh". As usual, this book by Trinity Press International is presented in concise numerical point form. By contrast with the other book reviewed nearby, I noted only one typographical error: "They are said to prophecyout 
of their own hearts" (78). The book concludes with a full bibliography (22 pages) and a document citation list (13 pages).

The real value of this paperback is its rich collection of texts and data pertaining to five religious figures in ancient lsrael: the king, the priest, the prophet, the diviner, and the sage. Besides the potential herein for preaching a series of sermons on religious professionals (leader, mediator, critic, healer, and teacher), the pastor might find here the impetus for a five session study/discussion of the Old Testament's foundational institutional functions and the presence or absence of their equivalents in contemporary religious society.

Roger W. Utti

Lutheran Theological Seminary

\section{An Introduction to the History of Israel and Judah}

J. Alberto Soggin

Valley Forge, PA: Trinity Press International, 1993 (2nd edition) xxii +474 pages, $\$ 30.00$ US Paperback

The pastor who wishes to be in the know on what is and what is not an "assured chapter" in Israel's history should find this work serviceable and informative. Personally l would not hesitate to use this book as a required textbook for a "history of Israel" course.

First, as Professor of Hebrew Language and Literature at the University of Rome and Visiting Lecturer at the Pontifical Biblical Institute, J. Alberto Soggin is eminently qualified to write this book. He is the author of a monograph on kingship in Israel (BZAW 104, 1967), two commentaries on Joshua (1972) and Judges (1981) in the Old Testament Library Series, and an Old Testament introduction now in its 3rd edition (1989). As an Italian scholar he brings to the subject the best and latest of European scholarship.

Second, this book is a completely rewritten update of his earlier Introduczione alla Storia d'Israele e di Giuda (1983). Virtually every page of the earlier text has had to be changed as a result of ten intervening years of scholarship. Ideologically, the book is more minimalist than maximalist in its approach.

Third, I like the structure, bibliographies, and appendices of this paperback. Its four parts are presented in numerical point style with clear, succinct paragraphing and titling. Part One deals with introductory problems, including methodological and historiographical questions. As to 